\title{
Loss of persistence of the North Atlantic Oscillation and its biological implication
}

\author{
Joachim W. Dippner ${ }^{1 *}$, Caroline Möller ${ }^{1}$ and Ingrid Kröncke ${ }^{2}$ \\ ' Department for Biological Oceanography, Leibniz Institute for Baltic Sea Research Warnemünde, Rostock, Germany \\ ${ }^{2}$ Department for Marine Research, Senckenberg am Meer, Wilhelmshaven, Germany
}

\author{
Edited by: \\ Martin Beniston, University of \\ Geneva, Switzerland \\ Reviewed by: \\ Nathaniel Kenneth Newlands, \\ Federal Government of Canada, \\ Canada \\ Sami Souissi, University of Lille 1 , \\ France \\ Anda Ikauniece, Latvian Institute of \\ Aquatic Ecology, Latvia \\ *Correspondence: \\ Joachim W. Dippner, Department for \\ Biological Oceanography, Leibniz \\ Institute for Baltic Sea Research \\ Warnemünde, Seestr. 15, \\ D-18119 Rostock, Germany \\ e-mail:dippner@ \\ io-warnemuende.de
}

Winter sea-level pressure fields in the northern hemisphere were analyzed with respect to regimes and regime shifts (RS). Classification of the North Atlantic Oscillation (NAO) patterns resulted in the identification of two longer lasting climate regimes: a persistent NAO- period from 1977 to 1988 followed by a persistent NAO+ period from 1989 to 2000. A further persistent NAO- period from 1956 to 1966 cannot be related to climate regime shifts. After 2000, the NAO lost its persistence and the autocorrelation disappeared, while the variance in the benthic data increased. The consequence was a decrease in potential predictability. The impact of the 1988/89 and 2000/2001 RS on the dominant species and taxonomic groups of benthic macrofauna as well as on benthic community structure was evaluated using an AMOEBA model, a quantitative method used in water management to represent the status of the ecosystem. The model confirmed the effects of the smooth RS in 1988/1989 and the abrupt RS in 2000/2001 on the macrofauna communities provided by earlier data analyses.

Keywords: persistence, regime shift, benthic macrofauna, North Atlantic Oscillation, composite analysis, AMOEBA model

\section{INTRODUCTION}

Biological RS in marine ecosystems often occur in connection with climate RS as documented in the North Pacific (Bond et al., 2003; Mantua, 2004), the North Atlantic (Drinkwater, 2006; Harris et al., 2013), the North Sea (Beaugrand, 2004; Schlüter et al., 2008), or the Baltic Sea (Möllmann et al., 2009) and result in reduction in species diversity. Changes in species composition, species richness and functional diversity affect the sustainability of biological resources (Cushing and Dickson, 1976; Binet, 1997; Avaria and Muñoz, 1989; Carrasco and Santander, 1989; Worm et al., 2006). Biological RS can be smooth, abrupt or discontinuous (Scheffer et al., 2001; Collie et al., 2004) depending on the nature of the external forcing. E.g., Carpenter and Brock (2006) have documented that a rising variance is an indicator for an abrupt RS. Those RS strongly influences the potential predictability of the biological system as documented for benthic community structure in the southern North Sea (Dippner et al., 2010).

Climate RS are often considered as changes in the trend of global mean air temperature. Yasunaka and Hanawa (2002) used empirical orthogonal function (EOF) analysis to evaluate the seasurface temperature (SST) and sea-level pressure (SLP) fields in the northern hemisphere and identified climate RS during 1925/26, 1945/46, 1957/58, 1971/72, 1976/77 and 1988/89. A climate RS can also occur when modes of climate variability are synchronized and the coupling strength between those modes simultaneously increases. In this case, the climate system becomes unstable and moves into a new state, as observed during 19101920, 1938-1945, 1976-1981, and 2001-2002 (Swanson and Tsonis, 2009). These periods were related to the turning points of the Atlantic Multidecadal Oscillation (AMO), (Sutton and Hodson, 2005), also called the Atlantic Multidecadal Variability, which is driven by variations in the Atlantic meridional overturning circulation (Gulev et al., 2013). The AMO has a periodicity of $\sim 60-80$ years (Schlesinger and Ramankutty, 1994). Thus, a relatively cold period at the beginning of the Twentieth century was followed by a warm period in the 1940s and 1950s, another cold period in the 1970s and 1980s and then a warm period in the 1990s (Ting et al., 2013).

Several different biological RS have been documented in the southern North Sea (Reid et al., 2001; Edwards et al., 2002; Beaugrand, 2004; Alheit et al., 2005; Schlüter et al., 2008; Dippner et al., 2010, 2012; Kröncke et al., 2013). Three prominent events occurred in the last century: the Russell Cycle in the English Channel in the 1920s, the so-called Gadoid outburst in the North Sea in the 1960s, and the "Great Salinity Anomaly" in 1977/1978. During the Russell Cycle herring and macrozooplankton were replaced by pilchards and small zooplankton (Russell, 1973; Coombs and Halliday, 2011), which coincided with the climate RS in the 1920s (Drinkwater, 2006). The system reversed in the 1940-1970. Parallel the Gadoid Outburst appeared in the 1960s in the North Sea (Cushing, 1984) a well-documented upsurge of five gadoid fish stocks. Between 1977 and 1978 the Great Salinity Anomaly appeared in the North Sea (Dickson et al., 1988), with substantial ecological consequences (Aebischer et al., 1990).

The biological RS, which occurred, together with climate RS, in $1988 / 1989$ and $2000 / 2001$ is the focus of this paper. Our scientific question is why is NAO and benthic macrofauna correlated after the climate RS in 1988/1989 and not after the RS in $2000 / 2001$ and what is the reason for the decrease of potential 
predictability? Using data analysis, we try to examine the underlying mechanisms, the dynamics of the two regime types, and their impacts on the dominant species and taxonomic groups of macrozoobenthos and their effects on benthic community structure in the southern North Sea.

\section{DATA AND METHODS \\ BENTHOS}

Macrofaunal samples were collected using a $0.2-\mathrm{m}^{2}$ van Veen grab. Sampling was carried out every spring from 1978 to 2012 at five different stations in the sublittoral zone off the island of Norderney. The stations were located at water depths between 10 and $20 \mathrm{~m}$ (Figure 1) and a single grab was taken at each one. Samples from all stations were treated as replicates for the area, since a multivariate comparison had shown no significant differences between the macrofaunal communities (Dörjes et al., 1986). The samples were sieved over a $0.63-\mathrm{mm}$ mesh and fixed in $4 \%$ buffered formaldehyde. Species number, abundance and biomass were determined. After sorting, the organisms were preserved in $70 \%$ alcohol. The samples were dried for $24 \mathrm{~h}$ at $85^{\circ} \mathrm{C}$ and burned for $6 \mathrm{~h}$ at $485^{\circ} \mathrm{C}$. Biomass was determined as ash-free dry weight per $\mathrm{m}^{2}$. The study area is representative for a wider area, because the Fabulina (Tellina) fabula community present in the study area is found in the entire coastal area of the south-eastern North Sea on fine sands (Kröncke et al., 2011).

Species were classified into feeding modes (interface-, surface-deposit-, subsurface-deposit-, and suspension-feeders, sediment-feeding polychaeta, predators and sand lickers) and distribution types (temperate, arctic-boreal, warm-temperate, coldtemperate) based on the literature (Fauchald and Jumars, 1979; Lincoln, 1979; Hartmann-Schröder, 1996; Wieking and Kröncke, 2001) and taxonomic groups (such as Crustacea, Nemertini, Polychaeta, Mollusca and Echinodermata). According to this classification, 196 macrofauna taxa were identified (81 crustacea, 59 polychaeta, 32 mollusca, 9 echinodermata and 15 others).

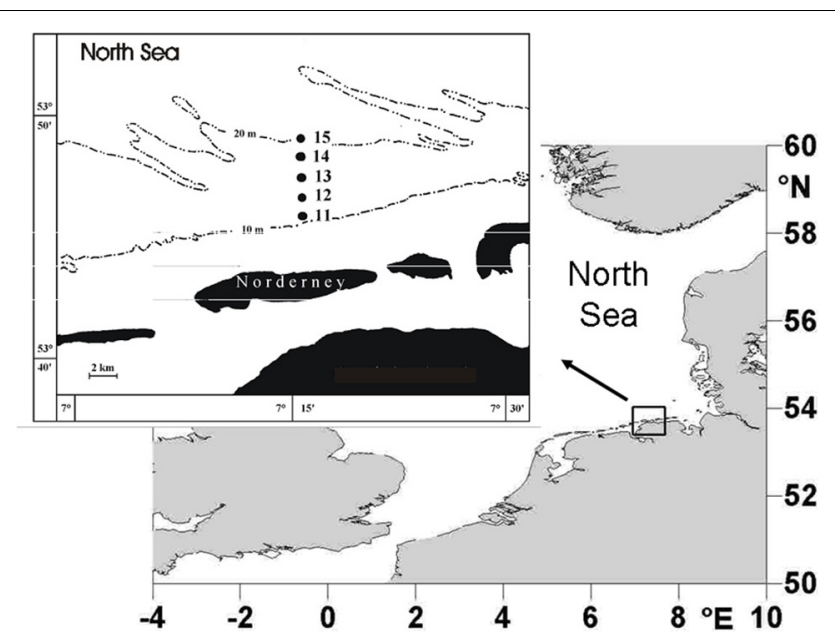

FIGURE 1 | Study area off the island of Norderney in the southern North Sea, showing the stations sampled from 1978 to 2012 (modified after Kröncke et al., 2013).
In addition, the long-term variability in the abundance of the most abundant single species, such as the sea urchin Echinocardium cordatum, the bivalve Tellina (Fabulina) fabula, the amphipod Urothoe poseidonis and the polychaetes Nephtyidae and Magelona spp., was analyzed. No gaps exist in all time series. More details are given in Kröncke et al. (2013).

\section{CLIMATE}

The following climate data sets were used for the analyses: (1) the NAO winter index from 1900 to 2013 (Hurrell, 1995), based on the difference between the normalized monthly SLP anomalies between Lisbon and Stykkisholmur, and (2) SLP winter (December to March average) anomalies of in the northern hemisphere poleward of $30^{\circ} \mathrm{N}$, as reported by the National Center for Environmental Prediction-National Center for Atmospheric Research (NCEP/NCAR) reanalysis (Kalnay et al., 1996) for the period 1949-2013.

\section{METHODS}

SLP composites of winter (December to March average) anomalies were constructed for each year from 1949 to 2013 (Table 1) and for the periods 1977-1988 and 1989-2000 (Figure 2) using the standard web-routine of NCEP/NCAR. Each SLP winter composite was classified according to Hurrell and Deser (2009). All benthos data were analyzed using a modified version of the classical AMOEBA model (Ten Brink et al., 1991). AMOEBA, a Dutch acronym for "a general method for ecosystem description and assessment” (Laane and Peters, 1993), is a quantitative method used in water management to represent the status of the ecosystem and possible developments. It is a graphical method in which numerous variables are plotted in a polar diagram and related to an arbitrary reference level. The advantage of the AMOEBA model is the holistic visualization of all changes in all variables in one diagram. The standardized benthos time series [zero mean and unit standard deviation (STD)] is separated in well-defined climatic regimes 1977-1988, 1989-2000, and 2001-2012. The regime means for each variable are computed and the differences between the climate regimes are plotted in a polar plot with respect to the long-term climatic means and the \pm 1 STD. According to Dippner et al. (2012), a RS is defined as a change in absolute STD larger than 0.5 .

The three regimes 1977-1988, 1989-2000, and 2001-2013 are analyses using autocorrelation functions. According to Von Storch and Zwiers (1999), autocorrelation function is given as:

$$
\rho(k)=\frac{\operatorname{Cov}\left(X_{t}, X_{t+k}\right)}{\operatorname{Var}(X)}
$$

$X_{t}$ a stationary time series of a real-valued random variable $X$. The autocorrelation function at lag $k$ is the correlation skill score for the $k$-lag persistence forecast of the time series. The autocorrelation function is computed according to Press et al. (1992). To evaluate the results, the Durbin-Watson test (Sargan and Bhargava, 1983) and decorrelation time (Von Storch and Zwiers, 1999) have been computed. The Durbin-Watson test is used to identify the presence of autocorrelation. If $e_{t}$ is the residual associated with 
Table 1 | Composite analysis of sea-level pressure (SLP) anomalies during winter (December-March) according to the classification given by Hurrell and Deser (2009).

\begin{tabular}{|c|c|c|c|c|c|c|c|c|c|}
\hline Year & Type & Year & Type & Year & Type & Year & Type & Year & Type \\
\hline & & 1952 & $\mathrm{NAO}-$ & 1972 & B & 1992 & $\mathrm{NAO}+$ & 2012 & $\mathrm{NAO}+$ \\
\hline & & 1954 & B & 1974 & B & 1994 & $\mathrm{NAO}+$ & & \\
\hline & & 1955 & $A R$ & 1975 & $\mathrm{NAO}+$ & 1995 & $\mathrm{NAO}+$ & & \\
\hline & & 1958 & NAO- & 1978 & $\mathrm{NAO}-$ & 1998 & $\mathrm{NAO}+$ & & \\
\hline & & 1959 & B & 1979 & $\mathrm{NAO}-$ & 1999 & $\mathrm{NAO}+$ & & \\
\hline & & 1960 & NAO- & 1980 & $\mathrm{NAO}-$ & 2000 & $\mathrm{NAO}+$ & & \\
\hline & & 1961 & B & 1981 & $A R$ & 2001 & NAO- & & \\
\hline & & 1962 & $\mathrm{NAO}-$ & 1982 & NAO- & 2002 & $\mathrm{NAO}+$ & & \\
\hline & & 1966 & NAO- & 1986 & NAO- & 2006 & NAO- & & \\
\hline & & 1967 & $\mathrm{NAO}+$ & 1987 & $\mathrm{NAO}-$ & 2007 & $\mathrm{NAO}+$ & & \\
\hline & & 1968 & $A R$ & 1988 & NAO- & 2008 & $\mathrm{NAO}+$ & & \\
\hline 1949 & $\mathrm{NAO}+$ & 1969 & NAO- & 1989 & $\mathrm{NAO}+$ & 2009 & B & & \\
\hline 1950 & $\mathrm{NAO}-$ & 1970 & $A R$ & 1990 & $\mathrm{NAO}+$ & 2010 & NAO- & & \\
\hline
\end{tabular}

The four classified modes are the positive (NAO+) and negative (NAO-) phases of the North Atlantic Oscillation and the strong anticyclonic ridges over Scandinavia (B, blocking) and western Europe (AR, Atlantic Ridge). The data source is the NCEP/NCAR reanalysis data (Kalnay et al., 1996). Yellow, blue and pink shading distinguishes the different regimes: a persistent NAO-mode from 1956 to 1967 and from 1977 to 1988 and a persistent NAO+ mode from 1989 to 2000 . There is no persistent signal after 2000

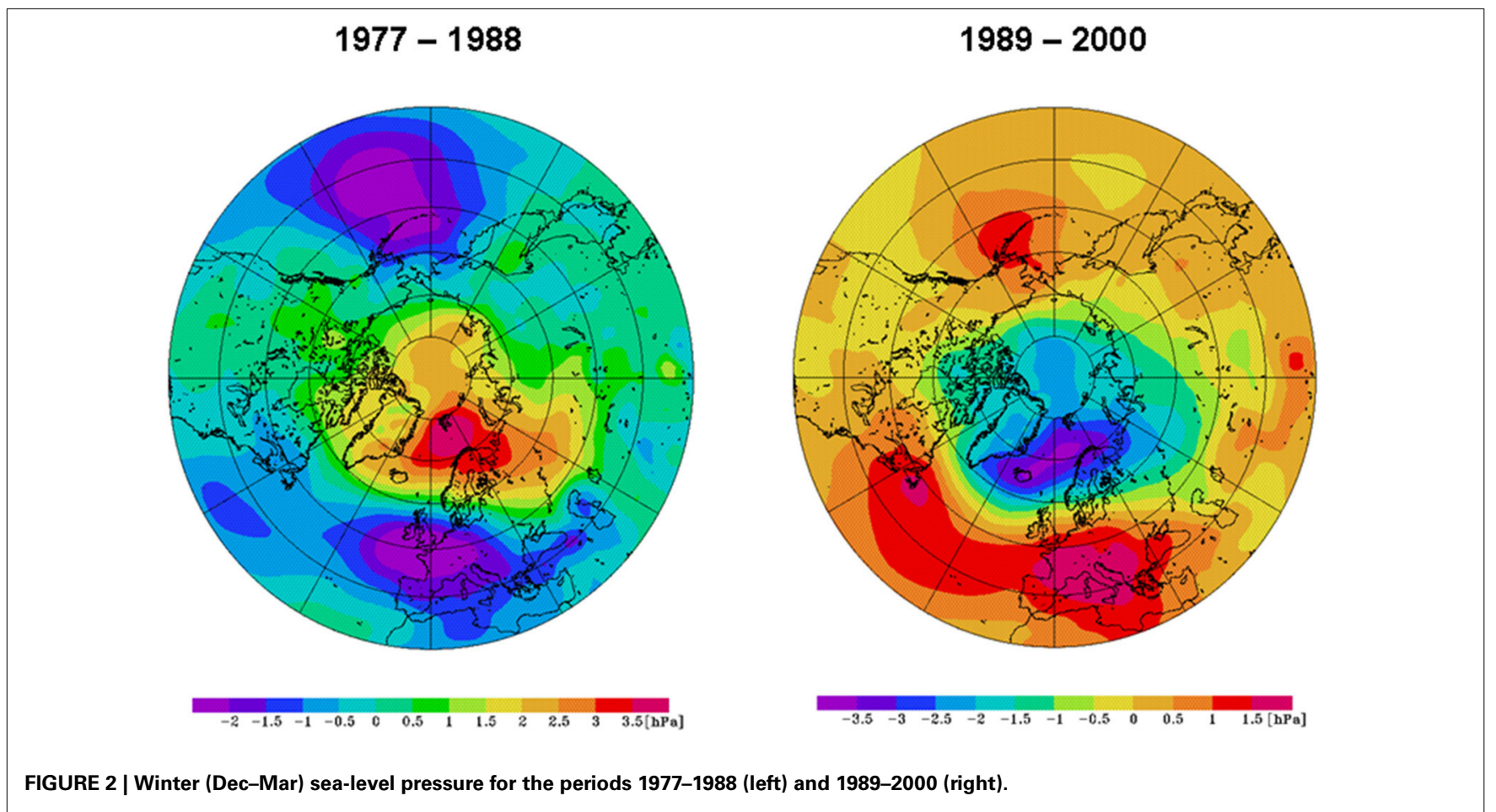


the observation at time $t$, then the Durbin-Watson test is:

$$
d=\frac{\sum_{t=2}^{T}\left(e_{t}-e_{t-1}\right)^{2}}{\sum_{t=1}^{T} e_{t}^{2}}
$$

$T$ is the number of observations. The value of $d$ lies always between 0 and 4 and $d=2$ indicates no autocorrelation. According to Von Storch and Zwiers (1999) the decorrelation time is defined as:

$$
\tau_{D}=\left[1+2 \sum_{k=1}^{\infty} \rho(k)\right] \Delta t
$$

$\Delta t$ is a time increment. The number of the decorrelation time makes sense as a characteristic time scale when dealing with red noise processes or long-term climate variability.

\section{RESULTS}

Based on the NCEP/NCAR reanalysis data of daily SLP patterns (Kalnay et al., 1996), Hurrell and Deser (2009) classified the NAO into four modes: its positive and negative phase $\mathrm{NAO}+$ and $\mathrm{NAO}-$ ) and the strong anticyclonic ridges over Scandinavia (B, blocking mode) and western Europe (AR, Atlantic Ridge mode). All patterns of the winter SLP anomalies from 1949 to 2013 were classified according to Hurrell and Deser (2009). The results (Table 1) were in good agreement with those shown in Figure 11 of their publication. The period 1977-1988 (light blue in Table 1) was characterized by a persistent NAO- mode, as $75 \%$ of the winter SLP patterns were NAO-. By contrast, the period 19892000 (pink in Table 1) was dominated by a persistent NAO+ mode, with $83 \%$ of the patterns being NAO+. A composite of the two regimes (Figure 2) indicated a ridge over the North Pole, a trough over Western Europe in the Atlantic area and a pronounced Aleutian low in the North Pacific during 1977-1988. Between 1989 and 2000, a trough over the North Pole and two ridges in the Atlantic and over Europe and the Pacific dominated.

The autocorrelation function of the time series (Figure 3) of the winter NAO for the periods 1977-1988 and 1989-2000 showed a positive correlation up to a lag of 3 years, whereas for the period 2001-2013 no autocorrelation could be identified caused by a rapid decay and negative correlations at lags from 1 to 3 years. The Durbin-Watson test was $d=1.52$ for the period $1977-1988, d=0.83$ for the period 1989-2000 indicating a high positive correlation, and $d=1.96$ for the period $2001-2013$ indicating no autocorrelation (Table 2). The decorrelation time was $\tau_{D}=0.55$ for the period $1977-1988, \tau_{D}=3.39$ for the period 1989-2000, and $\tau_{D}=0.26$ for the period 2001-2013 (Table 2). A decorrelation time less than unity for the period 1977-1988 was surprising because we expected a value greater unity indicating the presence of red noise processes due to the persistent NAO - pattern (Table 1, Figure 2). The period 1989-2000 has a decorrelation time larger than unity. This period was characterized by a high autocorrelation and long-term climate variability. The period 2001-2013 has the smallest decorrelation time, which is close to white noise.
During RS1 (1988/1989), all benthic macrofaunal variables for the southern North Sea were within the \pm 1 STD of the long-term climatic mean (Figure 4). Nevertheless, a few small shifts (STD > 0.5 ) occurred that slightly changed the structure of the benthic system. Specifically, there was a significant decrease in the abundance of warm-temperate species, polychaetes, U. poseidonis and Magelona spp. and a significant increase in both total biomass and the abundance of crustaceans, echinodermata, mollusca and T. fabula (Figure 4).

The impact of RS2 (2000/2001) on the benthic community structure was much stronger than that of RS1, because in the latter case few variables exceeded the \pm 1 STD interval (Figure 4). Except subsurface deposit feeders, all feeding modes increased significantly, as did all distribution types except the arctic boreal type. Increases in total biomass and abundance and in the abundance of all dominant taxonomic groups except crustaceans were determined. The abundances of the sea urchin E. cordatum and the amphipod $U$. poseidonis increased as well.

\section{DISCUSSION}

Longer-lasting persistent regimes were identified in the periods 1977-1988 and 1989-2000 (Table 1, Figure 2). After the climate RS in 1976/77, a pronounced NAO- pattern lasted until the climate RS in $1988 / 89$, when a persistent NAO+ pattern occurred, which ended with the climate RS of 2000/01. After

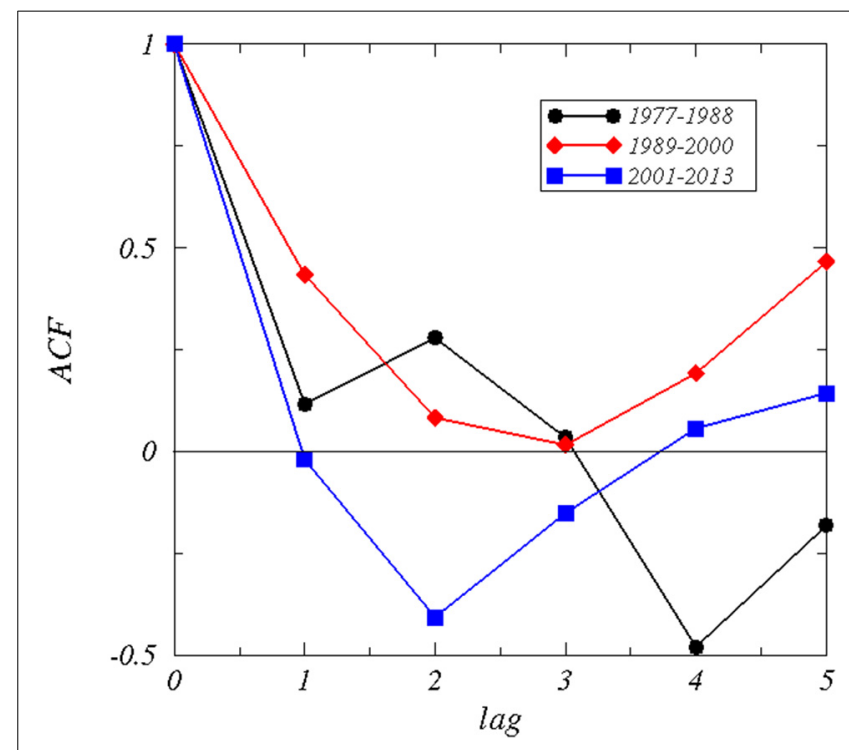

FIGURE 3 | Autocorrelation function of winter NAO for different periods.

Table 2 | Different statistical properties of the analysis of autocorrelation function for the three analyzed periods.

\begin{tabular}{lccc}
\hline Period & 1977-1988 & 1989-2000 & 2001-2013 \\
\hline First autocorrelation coefficient & 0.12 & 0.43 & -0.02 \\
Durbin-Watson statistics & 1.52 & 0.83 & 1.96 \\
De-correlation time & 0.55 & 3.39 & 0.26
\end{tabular}




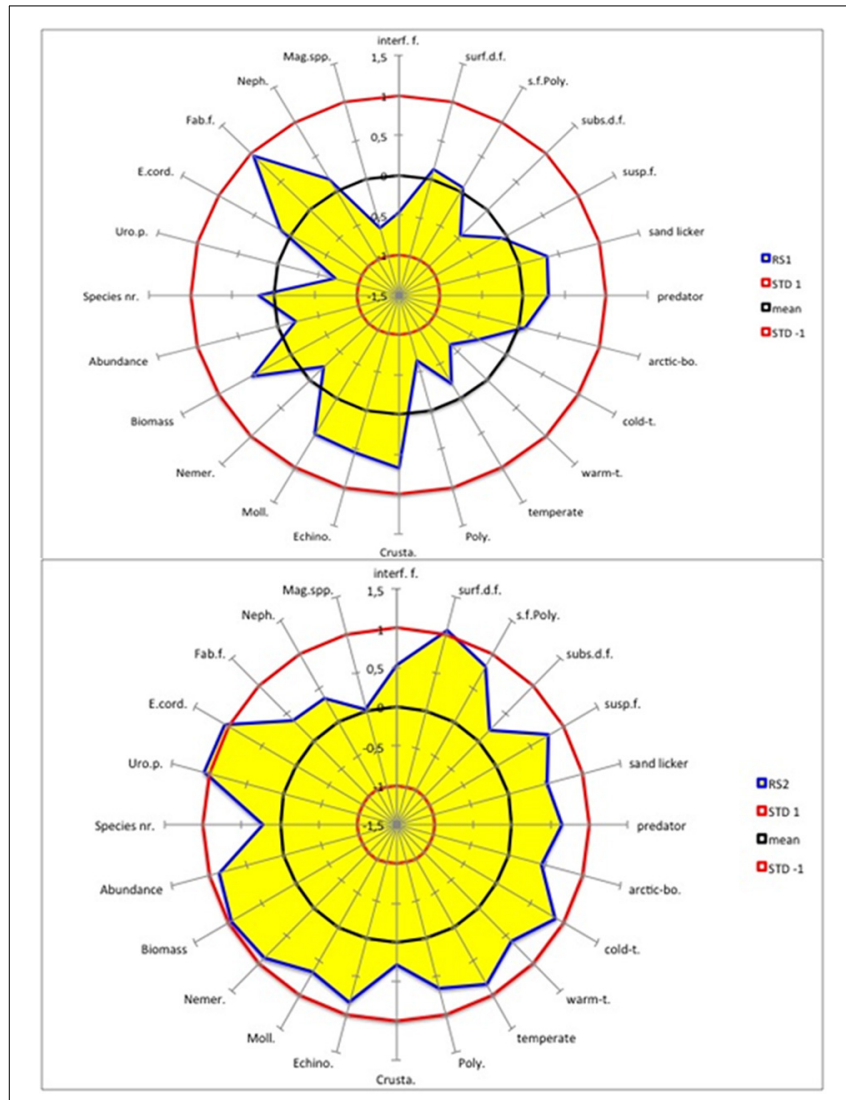

FIGURE 4 | AMOEBA model for the southern North Sea benthos (blue line as the edge of the yellow area). Two regime shifts (RS) are shown. RS1 shows the differences in the standardized spring values of the regime 1989-2000 minus those of 1977-1988 (upper panel). RS2 shows the differences in the standardized spring values of the regime 2001-2012 minus those of 1989-2000 (lower panel). The black circle marks the long-term climatic mean value, and the two red circles the \pm 1 STD. The acronyms are in clockwise direction: Interface-feeders (interf.f.), surface-deposit-feeders (surf.d.f.), sediment-feeding polychaeta (s.f.Poly.), subsurface-deposit-feeders (subs.d.f.), suspension-feeders (susp.f.), arctic-boreal (arctic-bo.), cold-temperate (cold-t.), warm-temperate (warm-t.), Polychaeta (Poly.), Crustacea (Crusta.), Echinodermata (Echino.), Mollusca (Moll.), Nemertini (Nemer.), Urothoe poseidonis (Uro.p.), Echinocardium cordatum (E.cord.), Tellina (Fabulina) fabula, (Fab.f.), Nephtyidae spp. (Neph.), and Magelona spp. (Mag.spp.).

2000, there was no persistent SLP pattern in the North Atlantic. According to the classification of Hurrell and Deser (2009), the period between 2001 and 2013 was characterized by a frequency distribution of the four modes, NAO-, NAO+, $\mathrm{B}$, and $\mathrm{AR}$, of $4,4,2$, and 3 . During this period, the NAO time series lost its autocorrelation, its persistence and hence its potential predictability.

From 1949 until the climate RS of 1976/77, the SLP pattern seemed to be unstructured except during the period 1956-1966 (light yellow in Table 1). For 11 years, the dominant condition was NAO- ( $72 \%$ frequency) and it was not framed by climate RS. The climate RS of 1957/58 and 1971/72 were not identified either in the analysis of Swanson and Tsonis (2009) or in our NAO winter composite analysis. A possible explanation is that these climate
RS mostly occurred in the Pacific and not in the North Atlantic (Yasunaka and Hanawa, 2002).

The identified regimes have a duration of around 10 years. This is in agreement with the first EOF modes for sea-ice concentration, SLP, $500 \mathrm{hPa}$ height, and $850 \mathrm{hPa}$ temperature, which since the 1960s have shown an oscillatory behavior with a period of around 10 years (Slonosky et al., 1997). The approximately 10year climate cycle in the Arctic and subarctic was characterized by a clockwise propagating signal in sea-ice concentration anomalies and a standing oscillation in SLP anomalies (Mysak and Venegas, 1998).

Over longer time scales, the North Atlantic was forced by the AMO, which had its turning point in the mid-1970s, with temperatures increasing up to the year 2000 (Sutton and Hodson, 2005). In a recent paper, Harris et al. (2013) presented an EOF analysis of the North Atlantic SST and demonstrated that the time coefficients of the first EOF are related to the AMO and those of the second EOF to the East Atlantic Pattern (Wallace and Gutzler, 1980); whereas the time coefficients of the third EOF obey the $\mathrm{NAO}$, with a local maximum of the EOF pattern in the southern North Sea. After RS1 (1988/1989), both the AMO and NAO were in positive mode. This period was also characterized by a warming caused by increased heat transport from the tropics to the extra-tropics (Hoerling et al., 2001). The switch from a negative to a positive NAO pattern (Figure 2) also caused an increase in the westerly wind, which enhanced the inflow of Atlantic water into the southern North Sea through the English Channel.

Among the effects of this enhanced inflow was the appearance of non-native warm-temperate species in the southern North Sea, such as the thresher shark Alopias vulpius (Stehmann, pers. comm.), the dinoflagellates Lepidodinium viride (Elbrächter, pers.com.) and Gymnodinium catenatum (Nehring, 1994) in the pelagial, the angular crab Goneplax rhomboides (Neumann et al., 2010) and the Pacific Oyster Crassostera gigas (Markert et al., 2010) in the benthos, as well as several fish species (Ehrich et al., 2007). Kröncke et al. (1998) reported an increase in macrofaunal abundance, species number and biomass after 1988. Although changes in the marine ecosystem were documented during the biological RS of 1988/1989, for only a few variables were the change larger than 0.5 STD (Figure 4), indicating a smooth RS (Dippner et al., 2010). The smooth biological RS in 1988/1989 significantly altered the macrofaunal community structure and was associated with rising SST, an NAO+ pattern and increased storm frequency. These factors also enhanced primary production in coastal North Sea regions and plankton blooms occurred earlier in the year (Reid et al., 1998). During this period, both native warm-temperate species and other bivalve species seemed to benefit from the SST-related increase in primary production and from the availability of food in the southern North Sea (Kröncke et al., 2013).

Besides the changes in the southern North Sea, the climate RS also caused a global biological response. In the North Pacific, a RS was detectable in 69 biological and 31 climatic time series during the RS 1976/1977 and 1988/1989 (Mantua, 2004). In the North Atlantic zooplankton decreased after 1988 whereas phytoplankton color index increased (Harris et al., 2013). In the same year in the North Sea a strong increase in temperate species and decrease 
in subarctic species of calanoid copepods occurred (Beaugrand, 2004), a strong increase in spring phytoplankton in surface waters (Alheit et al., 2005) and a strong increase in the abundance of dinoflagellates and decapods (Edwards et al., 2002). Changes in benthic community structure and functional diversity after 1988 were found for the entire North Sea (Neumann et al., 2008, 2009; Neumann and Kröncke, 2011; Schückel et al., 2010; Kröncke, 2011; Kröncke et al., 2011). The RS 1988/1989 was detectable in 39 variables in the North Sea (Schlüter et al., 2008) and in 52 biotic and abiotic variables in the Baltic Sea (Möllmann et al., 2009).

Kröncke et al. (2013) also found an increase in the abundance of native warm-temperate species. Thus, the decrease in warmtemperate species computed by the AMOEBA model is artefactual, as supported by the dominance of the polychaete Lagis koreni after the extreme winter of 1978/1979. In fact, the strong presence of $L$. koreni as a native warm-temperate species caused the bias in the model, because the species is also an r-selective colonizer that after cold winters feeds on buried dead organic material. The latter ecological preference of this species was probably more important after the cold winter than its preference for warmer temperatures.

RS2 (2000/2001) was a global climate RS (Swanson and Tsonis, 2009) coupled with an abrupt biological RS (Dippner et al., 2010). The consequence was a decrease in potential predictability. The NAO was a very good predictor in forecasting benthic time series (Dippner and Kröncke, 2003); however, after 2000 the forecasts failed, perhaps reflecting the loss in persistence and the disappearance of the autocorrelation. After 2000, the time series of the winter NAO behaved like a chaotic time series or white noise. During this period, when the southern North Sea was mainly forced by SST anomalies and meridional winds, the abundances of juvenile sea urchins and single species increased dramatically. A direct comparison of RS2 (2000/2001) with RS1 $(1988 / 1989)$ identified a much stronger increase in variance during RS2. Increases in ecosystem variability are thought to indicate long-lasting reorganizations of complex systems such as ecological RS. In ecology, the variance of a population/system was previously used as a measure of temporal stability, with increasing variance as an indicator of an abrupt biological RS (Carpenter and Brock, 2006). This relationship is useful for the identification of biological RS and our findings confirm these results; however, the appearance of an abrupt biological RS has the disadvantage of a lower potential predictability. Such an abrupt RS also occurred in the North Atlantic where the variance of phytoplankton communities suddenly increased (Harris et al., 2013). In the North Pacific, the biomass of three cold water northern species Pseudocalanus mimus, Acartia longiremis and Calanus marshallae drastically increased in 2000 indicating an abrupt RS (Peterson and Schwing, 2003).

Long-term studies are essential for understanding the natural variability of species composition, dominance structure and the functional diversity of benthic communities in relation to natural environmental drivers, all of which are affected by climate change (Spencer et al., 2011). As a contribution to ecosystembased management, they are also necessary to assess the effect of human activities on benthic communities. Long-term benthic studies in the North Sea have revealed regional differences in the structural and functional-responses of communities to climate RS (Frid et al., 2009). These responses reflect both the complex benthic interactions as a function of the changing climate and the associated species-specific responses. Changes in stratification or primary production or a temporal mismatch between primary producers and consumers, for example, can have cascading effects on the entire food web, potentially affecting benthic organisms throughout all of their developmental stages (Schückel et al., 2010).

The approach presented here, while demonstrated on the macrofauna of the southern North Sea, is generally applicable to all geographical regions in the world and all areas in marine biology, from species level (Dippner et al., 2001), over communities (Hannig et al., 2006) up to biodiversity (Araujo and Rahbek, 2006). Climate change is projected to be an increasingly important source of stress for ecosystems, both directly and through complex interactions with other stressors such as habitat loss and eutrophication (Staudt et al., 2013). The increase in variance in relation to the detailed changes given in Kröncke et al. (2013), indicate a shift in macrofauna community structure with increasing SST. Additional increase in non-native species might lead to changes in functional diversity and, thus, can probably change the ecosystem functions and services of the coastal system of the south-eastern North Sea. Changes in the frequency and magnitude of extreme events will result in biological RS (Grimm et al., 2013), whereas changes in ecosystem productivity, food-chain relationships or climate feedback are likely to have important societal consequences. Thus, increasing variance serves as an early warning of an abrupt biological RS and is therefore useful information for practical aspects of the sustainable management of marine ecosystems, for those of integrated coastal zone management, for the conservation of ecosystems goods and services, ecosystem health (Halpern et al., 2012), and for the implementation of the EU Marine Strategy Framework Directive (MSFD, 2008/56/EC). But it remains to be seen how the persistence of the NAO will develop and whether and to what extent the benthic ecosystem is able to recover after an abrupt biological RS.

\section{ACKNOWLEDGMENTS}

We thank the captains and crews of the RV "Senckenberg" for their help with sampling throughout the years. We are indebted to our colleagues for technical assistance in sampling, sample processing, biomass determination and taxonomic identification. Thanks also to M. Elbrächter and M. Stehmann for helpful discussions. Joachim W. Dippner and Caroline Möller acknowledge funding from AMBER (BONUS + ERANET Project) by national funding agencies and from the EU (in Germany from the BMBF, project number 03F0485A). The paper is a contribution to the LOEWE funded Research Centre Biodiversity and Climate (BiK-F).

\section{REFERENCES}

Aebischer, N. J., Coulson, J. C., and Colebrook, J. M. (1990). Parallel long-term trends across four marine trophic levels and weather. Nature 347, 753-755. doi: $10.1038 / 347753 \mathrm{a} 0$

Alheit, J., Möllmann, C., Dutz, J., Kornilovs, G., Loewe, P., Mohrholz, V., et al. (2005). Synchronous ecological regime shifts in the central Baltic and 
the North Sea in the late 1980s. ICES J. Mar. Sci. 62, 1205-1215. doi: 10.1016/j.icesjms.2005.04.024

Araujo, M. B., and Rahbek, C. (2006). How does climate change affect biodiversity? Science 313, 1396-1397. doi: 10.1126/science.1131758

Avaria, S., and Muñoz, P. (1989). Effects of the 1982-1983 El Niño on the marine phytoplankton off northern Chile. J. Geophys. Res. 92, 14369-14382.

Beaugrand, G. (2004). The North Sea regime shift: evidence, causes, mechanisms and consequences. Prog. Oceanogr. 60, 245-262 doi: 10.1016/j.pocean.2004.02.018

Binet, D. (1997). Climate and fisheries in the Canary and Guinea currents 1964-1993: the role of trade winds and the southern oscillation. Oceanol. Acta 20, 177-190.

Bond, N. A., Overland, J. E., Spillane, M., and Stabeno, P. (2003). Recent shifts in the state of the North Pacific, Geophys. Res. Lett. 30, 2183. doi: 10.1029/2003GL018597

Carpenter, S. R., and Brock, W. A. (2006). Rising variance: a leading indicator of ecological transition. Ecol. Lett. 9, 311-318. doi: 10.1111/j.14610248.2005.00877.x

Carrasco, S., and Santander, H. (1989). The El Niño event and its influence on the zooplankton off Peru. J. Geophys. Res. 92, 14405-14410. doi: 10.1029/JC092iC13p14405

Collie, J. S., Richardson, K., and Steele, J. H. (2004). Regime shifts: can ecological theory illuminate the mechanisms? Prog. Oceanogr. 60, 281-302. doi: 10.1016/j.pocean.2004.02.013

Coombs, S., and Halliday, N. (2011). The Russell Cycle. An update and Review of Trends in Zooplankton and Fish Larvae off Plymouth 1924-2009. Plymouth: Occasional Publications of the Marine Biological Association No. 24, 27.

Cushing, D. H. (1984). The gadoid outburst in the North Sea, J. Cons. Int. Explor. Mer. 41, 159-166. doi: 10.1093/icesjms/41.2.159

Cushing, D. H., and Dickson, R. R. (1976). The biological response in the sea to climate change. Adv. Mar. Biol. 14, 2-122.

Dickson, R. R., Meincke, J., Malberg, S. A., and Lee, A. J. (1988). The "great salinity anomaly" in the northern North Atlantic 1968-1982. Prog. Oceanogr. 20, 103-151. doi: 10.1016/0079-6611(88)90049-3

Dippner, J. W., Hänninen, J., Kuosa, H., and Vuorinen, I. (2001). The influence of climate variability to the zooplankton abundance in the Northern Baltic Archipelago Sea (SW Finland). ICES J. Mar. Sci. 58, 569-578. doi: 10.1006/jmsc. 2001.1048

Dippner, J. W., Junker, K., and Kröncke, I. (2010). Biological regime shifts and changes in predictability. Geophys. Res. Lett. 37, L24701. doi: 10.1029/2010GL045696

Dippner, J. W., and Kröncke, I. (2003). Forecast of climate induced change in marine ecosystems. Clim. Res. 25, 179-182 doi: 10.3354/cr025179

Dippner, J. W., Möller, C., and Hänninen, J. (2012). Regime shifts in North Sea and Baltic Sea: a comparison. J. Mar. Syst. 105-108, 115-122. doi: 10.1016/j.jmarsys.2012.07.001

Dörjes, J., Michaelis, H., and Rhode, B. (1986). Long-term studies of macrozoobenthos in the intertidal and shallow subtidal habitats near the island of Norderney (East Frisian coast, Germany). Hydrobiologia 142, 217-232. doi: 10.1007/BF00026761

Drinkwater, K. F. (2006). The regime shift of the 1920s and 1930s in the North Atlantic. Prog. Oceanogr. 68, 134-151. doi: 10.1016/j.pocean.2006.02.011

Edwards, M., Beaugrand, G., Reid, P. C., Rowden, A. A., and Jones, M. B. (2002). Ocean climate anomalies and the ecology of the North Sea. Mar. Ecol. Prog. Ser. 239, 1-10. doi: 10.3354/meps239001

Ehrich, S., Adlerstein, S., Brockmann, U., Floeter, J. U., Garthe, S., Hinz, H., et al. (2007). 20 years of the German small-scale bottom Trawl Survey (GSBTS): a review. Senckenb. Maritima 37, 13-82. doi: 10.1007/BF03043206

Fauchald, K., and Jumars, P. A. (1979). The diet of worms: a study of polychaete feeding guilds. Oceanogr. Mar. Biol. Ann. Rev. 17, 193-284.

Frid, C. L. J., Garwood, P. R., and Robinson, L. A. (2009). Observing change in a North Sea benthic system: a 33 year time series. J. Mar. Syst. 77, 227-236. doi: 10.1016/j.jmarsys.2008.01.011

Grimm, N. B., Chapin, III. F. S., Bierwagen, B., Gonzalez, P., Groffman, P. M., Luo, Y., et al. (2013). The impact of climate change on ecosystem structure and function. Front. Ecol. Environ. 11:474-482. doi: 10.1890/120282

Gulev, S. K., Latif, M., Keenlyside, N., Park, W., and Koltermann, K. (2013). North Atlantic Ocean control on surface heat flux on multidecadal timescales. Nature 499, 464-468. doi: 10.1038/nature12268
Halpern, B. S., Longo, C., Hardy, D., McLeod, K. L., Samhouri, J. F., Katona, S. K., et al. (2012). An index to assess the health and benefits of the global ocean. Nature 488, 615-622. doi: 10.1038/nature11397

Hannig, M., Braker, G., Dippner, J. W., and Jürgens, K. (2006). Linking denitrifier community structure and prevalent biogeochemical parameters in the pelagial of the Central Baltic Proper (Baltic Sea). FEMS Microbiol. Ecol. 57, 260-271. doi: 10.1111/j.1574-6941.2006.00116.x

Harris, V., Edwards, M., and Olhede, S. C. (2013). Multidecadal Atlantic climate variability and its impact on marine pelagic communities. J. Mar. Syst. 133, 55-69. doi: 10.1016/j.jmarsys.2013.07.001

Hartmann-Schröder, G. (1996). "Annelida, Borstenwürmer, Polychaeta," in Die Tierwelt Deutschlands und der Angrenzenden Meeresteile, 2. Auflage, ed G. Fischer (Jena), 648.

Hoerling, M. P., Hurrell, J. W., and Xu, T. (2001). Tropical origin for recent North Atlantic climate change, Science 292, 90-92. doi: 10.1126/science.1058582

Hurrell, J. W. (1995). Decadal trends in the North Atlantic Oscillation: regional temperatures and precipitation. Science 269, 676-679. doi: 10.1126/science.269.5224.676

Hurrell, J. W., and Deser, C. (2009). North Atlantic climate variability: the role of the North Atlantic Oscillation. J. Mar. Syst. 78, 28-41. doi: 10.1016/j.jmarsys.2008.11.026

Kalnay, E., Kanamitsu, M., Kistler, R., Collins, W., Deaven, D., Gandin, L., et al. (1996). The NCEP/NCAR Reanalysis 40-year Project. Bull. Amer. Meteor. Soc 77, 437-471.

Kröncke, I. (2011). Changes in Dogger Bank macrofauna communities in the 20th century caused by fishing and climate. Estuar. Coast. Shelf Sci. 94, 234-245. doi: 10.1016/j.ecss.2011.06.015

Kröncke, I., Dippner, J. W., Heyen, H., and Zeiss, B. (1998). Long-term changes in the macrofauna communities off Norderney (East Frisia, Germany) in relation to climate variability. Mar. Ecol. Prog. Ser. 167, 25-36 doi: 10.3354/meps167025

Kröncke, I., Reiss, H., and Dippner, J. W. (2013). Effects of cold winters and regime shifts on macrofauna communities in shallow coastal regions. Estuar. Coast Shelf Sci. 119, 79-90. doi: 10.1016/j.ecss.2012.12.024

Kröncke, I., Reiss, H., Eggleton, J. D., Aldridge, J., Bergman, M. J. N., Cochrane, S., et al. (2011). Changes in North Sea macrofauna communities and species distribution between 1986 and 2000. Estuar. Coast. Shelf Sci. 94, 1-15. doi: 10.1016/j.ecss.2011.04.008

Laane, W. E. M., and Peters, J. S. (1993). Ecological objectives for management purposes: applying the AMOEBA approach. J. Aquat. Ecosyst. Heal. 2, 277-286. doi: 10.1007/BF00044031

Lincoln, R. J. (1979). British Marine Amphipoda: Gammaridea, London: British Museum.

Mantua, N. (2004). Methods for detecting regime shifts in large marine ecosystems: a review with approaches applied to North Pacific data. Prog. Oceanogr. 60, 165-182. doi: 10.1016/j.pocean.2004.02.016

Markert, A., Wehrmann, A., and Kröncke, I. (2010). Recently established Crassostrea-reefs versus native Mytilus-beds: differences in ecosystem engineering affects the macrofaunal communities (Wadden Sea of Lower Saxony, southern German Bight). Biol. Invasions 12, 15-32. doi: 10.1007/s10530-0099425-4

Möllmann, C., Diekmann, R., Müller-Karulis, B., Kornilovs, G., Plikshs, M., and Axe, P. (2009). Reorganization of a large marine ecosystem due to atmospheric and anthropogenic pressure: a discontinuous regime shift in the Central Baltic Sea. Global Change Biol. 15, 1377-1393. doi: 10.1111/j.1365-2486.2008.01814.x

MSFD. (2008/56/EC). Directive of the European Parliament and of the Council of 17. June 2008 Establishing a Framework for Community Action in the Field of Marine Environmental Policy (Marine Strategy Framework Directive). Strasbourg: Official Journal of the European Union, L 164/19.

Mysak, L. A., and Venegas, S. A. (1998). Decadal climate oscillation in the Arctic: a new feedback loop for atmosphere-ice-ocean interactions. Geophys. Res. Lett. 25, 3607-3610. doi: 10.1029/98GL02782

Nehring, S. (1994). Gymnodinium catenatum Graham (Dinophyceae) in Europe: a growing problem? J. Plankton Res. 17, 85-102. doi: 10.1093/plankt/17.1.85

Neumann, H., Ehrich, S., and Kröncke, I. (2008). Temporal variability of an epibenthic community in the German Bight affected by cold winter and climate. Clim. Res. 37, 241-251. doi: 10.3354/cr00769

Neumann, H., and Kröncke, I. (2011). The effect of temperature on the ecological functioning of epifauna in the German Bight. Marine Ecology 32(Suppl. 1), 49-57. doi: 10.1111/j.1439-0485.2010.00420.x 
Neumann, H., Kröncke, I., and Ehrich, S. (2010). Establishment of the angular crab Goneplax rhomboides (Linnaeus, 1758) (Crustacea, Decapoda, Brachyura) in the southern North Sea. Aquatic Invasions 5, S27-S30. doi: 10.3391/ai.2010.5. S1.007

Neumann, H., Reiss, H., Rakers, S., Ehrich, S., and Kröncke, I. (2009). Temporal variability of southern North Sea epifauna communities after the cold winter 1995/1996. ICES J. Mar. Sci. 66, 2233-2243. doi: 10.1093/icesjms/fsp203

Peterson, W. T., and Schwing, F. B. (2003). A new climate regime in northeast Pacific ecosystem. Geophys. Res. Lett. 30, 1896. doi: 10.1029/2003GL017528

Press, W. H., Teukolsky, S. A., Vetterling, W. A., and Flamnnery, B. P. (1992). Numerical Recipes. The Art of Scientific Computing. 2nd Edn., Cambridge: Cambridge University Press, 963.

Reid, C. P., Edwards, M., Hunt, H. G., and Warner, J. (1998). Phytoplankton changes in the North Atlantic. Nature 391, 546. doi: 10.1038/35290

Reid, P. C., Borges, M., and Svendson, E. (2001). A regime shift in the North Sea circa 1988 linked to changes in the North Sea horse mackerel fishery. Fish. Res. 50, 163-171 doi: 10.1016/S0165-7836(00)00249-6

Russell, F. S. (1973). A summary of observations on the occurrence of planktonic stages of fish off Plymouth 1924-1952. J. Mar. Biol. Ass. UK. 53, 347-356. doi: 10.1017/S0025315400022311

Sargan, J. D., and Bhargava, A. (1983). Testing residuals from least squares regression for being generated by the Gaussian random walk. Econometrica 51, 153-174. doi: 10.2307/1912252

Scheffer, M., Carpenter, S., Foley, J. A., Folke, C., and Walker, B. (2001). Catastrophic shifts in ecosystems. Nature 413, 591-596. doi: 10.1038/35098000

Schlesinger, M. E., and Ramankutty, N. (1994). An oscillation in the global climate system of period 65-70 years. Nature 267, 723-726. doi: 10.1038/367723a0

Schlüter, M. H., Merico, A., Wiltshire, K. H., Greve, W., and von Storch, H. (2008). A statistical analysis of climate variability and ecosystem response in the German Bight. Ocean Dyn. 58, 169-186. doi: 10.1007/s10236-008-0146-5

Schückel, U., Ehrich, S., and Kröncke, I. (2010). Temporal variability of three macrofauna communities in the northern North Sea. Estuar. Coast. Shelf Sci. 89, 1-11. doi: 10.1016/j.ecss.2010.04.006

Slonosky, V. C., Mysak, L. A., and Derome, J. (1997). Linking Arctic sea-ice and atmospheric circulation anomalies on interannual and decadal timescales. Atmos. Ocean 35, 333-366. doi: 10.1080/07055900.1997.9649596

Spencer, M., Birchenough, S. N. R., Mieszkowska, N., Robinson, L. A., Simpson, S. D., Burrows, M. T., et al. (2011). Temporal change in UK marine communities: trends or regime shifts. Marine Ecol. 32, 1-15. doi: 10.1111/j.14390485.2010.00422.x

Staudt, A., Leidner, A. K., Howard, J., Braumann, K. A., Dukes, J. S., Hansen, L. J., et al. (2013). The added complication of climate change: understanding and managing biodiversity and ecosystem. Front. Ecol. Environ. 11, 494-501. doi: $10.1890 / 120275$

Sutton, R. T., and Hodson, D. L. R. (2005). Atlantic forcing of North American and European summer climate. Science 309, 115-118. doi: 10.1126/science.1109496

Swanson, K. L., and Tsonis, A. A. (2009). Has the climate recently shifted? Geophys. Res. Lett. 36:L06711. doi: 10.1029/2008GL037022

Ten Brink, B. J. E., Hosper, S. H., and Colijn, F. (1991). A quantitative method for the description and assessment of ecosystems: the AMOEBA approach. Mar. Poll. Bull. 23, 265-270. doi: 10.1016/0025-326X(91)90685-L

Ting, M., Kushnir, Y., and Li, C. (2013). North Atlantic Multidecadal SST Oscillation: external forcing versus internal variability. J. Mar. Syst. 133, 27-38. doi: 10.1016/j.jmarsys.2013.07.006

Von Storch, H., and Zwiers, F. W. (1999). Statistical Analysis in Climate Research. Cambridge: Cambridge University Press, 495.

Wallace, J. M., and Gutzler, D. S. (1980). Teleconnections in the geopotential height field during the Northern Hemisphere winter. Mon. Weather Rev. 109, 784-812.

Wieking, G., and Kröncke, I. (2001). Decadal changes in macrofauna communities on the Doggerbank caused by large-scale climate variability. Senckenb. Maritima 32, 125-141. doi: 10.1007/BF03043023

Worm, B., Barbier, E. B., Beaumont, N., Duffy, J. E., Folke, C., Halpern, B. S., et al. (2006). Impacts of Biodiversity loss on ocean ecosystem services. Science 314, 787-790. doi: 10.1126/science.1132294

Yasunaka, S., and Hanawa, K. (2002). Regime shifts found in the Northern Hemisphere SST field. J. Met. Soc. Jap. 80, 119-135. doi: 10.2151/jmsj.80.119

Conflict of Interest Statement: The authors declare that the research was conducted in the absence of any commercial or financial relationships that could be construed as a potential conflict of interest.

Received: 17 April 2014; accepted: 29 August 2014; published online: 22 September 2014

Citation: Dippner JW, Möller C and Kröncke I (2014) Loss of persistence of the North Atlantic Oscillation and its biological implication. Front. Ecol. Evol. 2:57. doi: 10.3389/ fevo.2014.00057

This article was submitted to Interdisciplinary Climate Studies, a section of the journal Frontiers in Ecology and Evolution.

Copyright (C) 2014 Dippner, Möller and Kröncke. This is an open-access article distributed under the terms of the Creative Commons Attribution License (CC BY). The use, distribution or reproduction in other forums is permitted, provided the original author(s) or licensor are credited and that the original publication in this journal is cited, in accordance with accepted academic practice. No use, distribution or reproduction is permitted which does not comply with these terms. 